Bull. Fac. Agric., Cairo Univ., 58 (2007): 127-132.

\title{
PHYSICO-CHEMICAL PROPERTIES AND FATTY ACID COMPOSITION OF PRICKLY PEAR SEED OIL AND ANTIOXIDANT ACTIVITY OF ITS UNSAPONIFIABLE MATTER
}

(Received:17.9.2006)

\author{
By \\ Sh . A. Helmy \\ Food Science \& Technology Department, Faculty of Agriculture, Cairo University, Giza, Egypt.
}

\begin{abstract}
The chemical composition of prickly pear seeds (Opuntia ficus-indica L.) was determined. The results ascertained that prickly pear seeds have high contents of crude fibers, crude proteins and oil. The seeds were investigated as a source of oil which constituted $12.28 \%$ of the whole seed. The obtained data proved that the physico-chemical properties of the prickly pear seed oil (PPSO) such as specific gravity, refractive index, color, stability, acid value, iodine value and saponification value compared well with those properties of other commonly edible oils (e.g. soybean and corn oil). The results purported that (PPSO) has a high degree of total unsaturation, $84.86 \%$. Linoleic acid was found to be the dominant one which constituted $63.04 \%$, followed by oleic acid, $19.42 \%$ and palmitic acid, $10.7 \%$. Meanwhile, linolenic acid was found in a very low level. The unsaponifiable matter (USM) of prickly pear seed oil was extracted and analyzed using GC/MS. The results revealed that $\beta$ - sitosterol was the major component of the sterolic fraction (64.8\%) followed by campesterol (13.8\%), meanwhile, 24- methyl cycloarthenol was found to be the main component of the alcoholic fraction (48.8\%), followed by cycloarthenol (35.9\%). Also, the unsaponifiable matter of PPSO was examined for its antioxidant activity by using sunflower oil. The obtained results proved that the (USM) exhibited antioxidant activity, specially, at $1200 \mathrm{ppm}$, where the antioxidant activity resembled that of $200 \mathrm{ppm}$ of BHA (synthetic antioxidant). Furthermore, the antioxidant activity of (USM) at $1500 \mathrm{ppm}$ was superior to that of BHA. Therefore, prickly pear seed oil could be used as edible oil, besides, its unsaponifiable matter which exhibited a potent antioxidant activity to suppress lipid oxidation.
\end{abstract}

Key words:antioxidant activity, fatty acids, prickly pear,seed composition, prickly pear seed oil, unsaponifiable matter.

\section{INTRODUCTION}

Prickly pear, a member of the Cactaceae Family and a native to arid and semi arid regions, is widely distributed in many parts of the world such as Africa, Australia and Mediterranean basin. It contains high content of some chemical constituents which give added value to its fruit on a nutritional and technological functionality basis (Piga, 2004).

The potential supply of the fruit by-products may be enormous. Millions of pounds of fruit seeds are discarded yearly, resulting in disposal problems and proper utilization of these waste products could lead to important new sources of oil which could be used in functional foods (Ramadan and Morsel, 2003a). The seeds of the prickly pear fruit constitute about $10-15 \%$ of the pulp. These seeds contain about $12 \%$ oil, with a linoleic acid of $50.9 \%$. Thereon, PPSO could be extracted and used as an alimentary oil (Lopez and Burgos, 1973). Chiefly, the biological studies on rats purported that PPSO exhibited a significant decrease in serum glucose, total cholesterol and LDL-cholesterol in the treated rats (Ennouri, et al., 2005b). Also, the findings of Tan and Che Man (2000) purported that the lipid pattern of prickly pear seed was comparable with that of sunflower and grape seed oils.

Another point of view is the unsaponifiable matter of PPSO where sterols comprise the bulk of the unsaponifiable matter in many oils. They are of interest due to their antioxidant activity and impact on health. Recently, sterols have been added to vegetable oils as an example of a 
successful functional food. This type of product is now available and lowers blood LDL-cholesterol by around $10-15 \%$ as apart of a healthy diet (Ntanios, 2001).

Concerning the unsaponifiable matter presented in PPSO, Krifa et al. (1993) affirmed that the USM of PPSO constitutes high content of sterols, mainly, $\beta$ - sitosterol (67\%) and campesterol(13\%). Likewise, Ramadan and Morsel (2003b) and Kuti (2004) pronounced that PPSO contained $\gamma$ - tocopherol and $\beta$ - carotene. These compounds exhibited antioxidant activity, thus, it could be used as natural antioxidants instead of synthetic ones such as BHT and BHA, which have been suspected of being responsible for liver damage and carcinogenesis (Jassen, and Vries 1997).

The present investigation was planned to extract the oil of prickly pear seeds and determine the physico-chemical properties and fatty acid composition. Also, to separate the unsaponifiable matter of prickly pear seed oil and determine their composition using GC/MS, then, examine their antioxidative activity on refined sunflower oil.

\section{MATERIALS AND METHODS}

\subsection{MATERIALS}

\subsubsection{Fruit samples}

Mature prickly pear fruits, Opuntia ficusindica were purchased from El-Oboor Market, Cairo. The fruits were sorted, washed, dried and hand picked, separated into peel and pulp. The pulp was squeezed for the separation of the seeds.

\subsubsection{Sunflower oil and BHA}

Refined sunflower oil was obtained from Cairo for Oils and Soaps Co., Cairo, Egypt.

Butylated hydroxyl anisole (BHA) was purchased from Sigma Chemical Co., (London, Ltd. Poole).

\subsection{METHODS}

\subsubsection{Fruit physical measurements}

Whole fruits, pulp, peel and seed weights were determined and the percentage of each parameter was calculated according to the method of Duru and Turker (2005).

\subsubsection{Preparation of prickly pear seeds}

The seeds were washed with distilled water several times, air- dried at ambient temperature and then milled by hummer mill.

\subsubsection{Chemical composition of prickly pear seeds}

Moisture, total ash and crude fiber contents were determined according to AOAC method (AOAC, 1995). The oil yield was determined from seed powder of 5g (AOAC, 1995). Total nitrogen was determined by the Kjeldahl procedure and crude protein was calculated as N X 6.25. Total carbohydrates were calculated by difference.

\subsubsection{Extraction of prickly pear seed oil}

The seed powder oil was extracted with hexane in a soxhlet extractor for $9 \mathrm{hr}$ according to the method reported by Ennouri et al.(2005a). The organic phase was then removed using a rotary evaporator under reduced pressure. The oil was flushed with a stream of nitrogen and stored at $20^{\circ} \mathrm{C}$ in sealed tubes prior to analyses.

\subsubsection{Extraction of unsaponifiable matter}

The unsaponifiable matter was extracted according to the method of (AOCS, 1993), and then stored at $-20^{\circ} \mathrm{C}$ in sealed glass tubes prior to analyses and using.

2.2.6. Physico-chemical analysis of prickly pearseed oil

Specific gravity, refractive index, color (using Lovibond Tintometer), acid value, iodine number, peroxide value, saponification number and unsaponifiable matter of (PPSO) were determined according to the standard methods of AOCS (1993). Stability of oil was determined at $75^{\circ} \mathrm{C}$ as the method described by Banias et al., (1992).

\subsubsection{Determination of fatty acid composition}

The fatty acid composition of PPSO was analyzed by GC/MS after transesterification. Fatty acid methyl esters were prepared in the presence of $2 \mathrm{~N}$ potassium hydroxide in methanol and analyzed on a Hewlett-Packard model 5890 series gas chromatograph equipped with a flame ionization detector and a capillary column : carbowax $20 \mathrm{M}(0.3 \mathrm{~mm}$ internal diameter, $50 \mathrm{~m}$ length and $0.3 \mu \mathrm{m}$ film thickness). The operational conditions were: injector temperature $220^{\circ} \mathrm{C}$, detector temperature $275^{\circ} \mathrm{C}$, column temperature $50^{\circ} \mathrm{C}$ for $5 \mathrm{~min}$ then raised again to $240^{\circ} \mathrm{C}$ at rate of ci. Carrier gas was nitrogen at a flow of 1.2 $\mathrm{ml} / \mathrm{min}$ as mentioned by Ennouri et al., (2005a).

\subsubsection{Determination of unsaponifiable matter composition}

The unsaponifiable matter was sailinized prior to chromatographic analysis. The unsaponifiable matters were derivatized with the addition of pyridine $(0.5 \mathrm{ml})$, hexamethyl disilosane $(100 \mu \mathrm{l})$ and trimethyl chlorosilane $(40 \mu \mathrm{l})$. The sterols and triterpene alcohol were then centrifugated and the upper layer was analyzed using a Vrian CP- 3800 gas chromatography equipped with a flame ionization detector and a capillar column, ZEBRN ZB- 5; Phenomenex $(0.25 \mathrm{~mm}$ internal diameter, $30 \mathrm{~m}$ length and $0.25 \mu \mathrm{m}$ film thickness) was coupled to a mass spectrometer ( Saturn 2000 GC MS/MS). The oven temperature was fixed at 
$150^{\circ} \mathrm{C}$ for $5 \mathrm{~min}$ and then raised to $250^{\circ} \mathrm{C}$ at $15^{\circ} \mathrm{C} / \mathrm{min}$ and held for $20 \mathrm{~min}$. Carrier gas was helium at a flow of $1 \mathrm{ml} / \mathrm{min}$. Quantification of ompounds was carried out using the internal standard method (Bereau et al., 2003).

\subsubsection{Evaluation of antioxidant effectiveness}

The antioxidant activity of USM extracted from PPSO was measured. The oven test at $75^{\circ} \mathrm{C}$ was used as described by Economou, et al. (1991). Twenty- five grams of refined fresh sunflower oil was placed in $100 \mathrm{ml}$ open-mouthed beakers and used as control and another sample of oil with BHA (200 ppm) for comparison. Another samples of oil (25 g each) with different concentrations of USM $(200,400,600,800,1000,1200$ and 1500 ppm). The samples were covered with watch glasses and placed at $75^{\circ} \mathrm{C} \pm 1$ till rancidity took place. Peroxide value was determined according to the standard methods of AOCS (1993).

The induction periods (the time needed for the peroxide value to become 20) were determined by plotting the peroxide values of samples vs. time as described by Banias et al., (1992).

\subsubsection{Statistical analysis}

The collected results of the induction periods of sunflower oil as affected by USM addition were subjected to statistical analysis using one way analysis of variance according to the method of Snedecor and Cochran (1980). The LSD was calculated at $0.05 \%$ probability.

\section{RESULTS AND DISCUSSION}

The results manifested that the fruits of Prickly pear contained $51 \%$ peels, $41 \%$ pulp and $8 \%$ seeds. These results are in agreement with those obtained by Piga (2004) and Duru and Turker (2005).

\subsection{Chemical composition of prickly pear seeds}

The results of chemical composition of PPS are presented in Table (1). Oil extracted from PPS constituted $12.28 \%$ of the whole seeds. This result is in the same line with that obtained by Ramadan and Morsel (2003b) and Ennouri et al.,(2005a). Also, it could be observed that the seeds contained $15.22 \%$ moisture, $7.42 \%$ crude protein, $47.91 \%$ crude fibers, $2.32 \%$ total ash and $30.07 \%$ total carbohydrates.

The results of total ash and other extract were higher than that reported by Coskuner and Tekin (2003), while, crude fibers and total carbohydrates contents were lower than that obtained by the same authors. The observed differences could be probably due to the origin of the fruits. Meanwhile, these values are in accordance with the values found by Ennouri et al., (2005a).

\subsection{Physico-chemical properties of PPSO}

Table (1): Chemical composition of prickly pear seeds (dry wt. basis).

\begin{tabular}{lc}
\hline${ }^{\mathrm{a}}$ Constituents & $\mathrm{g} / 100 \mathrm{~g}$ \\
\hline Crude proteins & 7.42 \\
Crude fibers & 47.91 \\
Total ash & 2.32 \\
Ether extract & 12.28 \\
Total carbohydrates & 30.07 \\
\hline Moisture & 15.22 \\
\hline${ }^{\mathrm{a}}$ Means of three determinations.
\end{tabular}

${ }^{\mathrm{a}}$ Means of three determinations.

The PPSO had a light yellow color. The physico-chemical properties of PPSO are displayed in Table (2). From the results, it could be observed that low acid and peroxide values indicated that no hydrolytic and oxidative rancidity occurred during extraction of oil. Like most vegetable oils, PPSO had a relatively high iodine value (116), which reflects a high degree of unsaturation. Also, due to the iodine value, PPSO oil could be classified as a semi-drying oil. This value is higher than that obtained by Ennouri et al., (2005a) (116 vs. 101.5). PPSO also exhibited higher stability compared with that of sunflower oil (Table, 5), meanwhile, the average value of unsaponifiable matter was high as compared to other vegetable oils (3.42\%). This value is higher than that reported by Sawaya and Khan (1982) who purported that they were $1.96 \%$. Also, the result recorded for saponification number was higher than that value found by Ennouri et al.,(2005a) (190 vs. 169). The observed difference is possibly due to both of variety and origin of the fruits. Generally, all characteristics of PPSO are in closed levels with those of other common vegetables oils.

Table (2): Physico-chemical properties of prickly pear seed oil.

\begin{tabular}{ll}
${ }^{\mathrm{a}}$ Properties & \\
\hline Specific gravity $\left(25^{\circ} \mathrm{C}\right)$ & 0.904 \\
Refractive index $\left(25^{\circ} \mathrm{C}\right)$ & 1.478 \\
Color (Lovibond Tintometer) & $0.7 \mathrm{red}, 20.0$ yellow \\
Stability of oil (at $\left.75^{\circ} \mathrm{C}\right)$ & $3.9 \mathrm{hr}$ \\
Acid value as oleic & 0.94 \\
Iodine number $(\mathrm{Wijs})$ & 116 \\
Peroxide value (meq $\mathrm{O}_{2} / \mathrm{kg}$ oil) & 2.2 \\
Saponification number & 190 \\
Unsaponifiable matter $(\%)^{\mathrm{b}}$ & 3.42 \\
\hline${ }^{\mathrm{a}}$ Results are mean values of three determinations. \\
${ }^{\mathrm{b}}$ Result Result is avalue of one determination.
\end{tabular}

\subsection{Fatty acid composition of PPSO}

This study was conducted on fatty acid composition of PPSO; results are listed in Table 
(3). It could be noticed that, linoleic was found to be the dominant fatty acid (63.04\%). This result agreed well with that obtained by Sawaya and Khan, 1982 and Barbagallo and Spagna, (1999). Meanwhile, Ennouri et al. (2005a) reported a higher linoleic acid content than the obtained result $(73.3 \%$ vs. $63.04 \%)$. The recorded difference is possibly due to the degree of maturity of the fruits as reported by Coskuner and Tekin (2003). The second one was oleic acid, $19.42 \%$, followed by palmitic acid, $10.7 \%$ and stearic acid, $4.32 \%$. The oil contained $15.14 \%$ saturated, $21.54 \%$ mono-unsaturated and $63.32 \%$ poly unsaturated fatty acids. These results are approximately in agreement with those obtained by Krifa et al. (1993), who purported that these values comprised 18.0, 25.0 and $57.0 \%$, respectively. Also, it could be noticed that both total saturation and unsaturation ratio of PPSO are close to that of soybean oil. Meanwhile, linoleic acid content and total unsaturation of PPSO are nearer to that of corn oil (Table 3). In general, the higher level of unsaturation and particularly high level of linoleic in conjunction with low level of linolenic acid, which affects adversely the stability of the oil, indicated that PPSO might be an excellent potential source of edible oil for human and /or animal consumption as reported by Sawaya and Khan (1982) and Ennouri et al., (2005b). sterolic and alcoholic fractions. Concerning the sterolic fraction, the data revealed that five components, representing $94.9 \%$ of the total sterols were identified. Also, it could be noticed the preponderance of $\beta$-sitosterol (64.8\%, of the total sterols), followed by campesterol (13.8\%), stigmasterol (6.1\%), lanosterol (5.8\%) and $\Delta-5$ avenasterol (4.4\%). These results are lower than those obtained by Ramadan and Morsel (2003a) who reported that $\beta$-sitosterol comprised $72 \%$, followed by campesterol (18\%) while stigmasterol and lanosterol constituted 3\%. With reference to the alcoholic fraction, data indicated that the main components are 24- methyl cycloarthenol (48.8\%), followed by cycloarthenol (35.9\%) and $\beta$-amyrin $(6.4 \%)$. These values were higher than those in the work of Salvo et al., 2004, whereas, the values were $34.2,29.3$ and $2.2 \%$, respectively. These differences may be attributed to the variety fruits, besides, the conditions of determination. From the above mentioned results, it could be noticed the importance of unsaponifiable matter of PPSO, especially, the higher content of sterols, which have antioxidant activity and impact on health (Karifa et al., 1993, Ntanios, 2001 and Ramadan and Morsel, $2003 \mathrm{a \& b}$ ).

3.5. Antioxidant activity of unsaponifiable matter

Initially, the addition of USM at various concentrations did not affect either the color or the flavor of sunflower oil. The data of the oxidative

Table (3): Fatty acid composition of prickly pear seed oil compared with some edible oils.

\begin{tabular}{|c|c|c|c|c|c|}
\hline Fatty acid & $\begin{array}{c}\text { Prickly pear } \\
\text { seed oil }\end{array}$ & Soybean* oil & Corn oil ${ }^{a}$ & $\begin{array}{c}\text { Sunflower* } \\
\text { oil }\end{array}$ & $\begin{array}{c}\text { Cotton seed } \\
\text { oil } \\
\end{array}$ \\
\hline Myristic $\mathrm{C}_{14: 0}$ & 0.12 & 0.2 & $-b$ & - & 0.7 \\
\hline Palmitic $\mathrm{C}_{16: 0}$ & 10.7 & 10.7 & 11.0 & 6.0 & 22.7 \\
\hline Palmitoleic $\mathrm{C}_{16: 1}$ & 2.12 & 0.3 & - & 0.1 & 0.6 \\
\hline Stearic $\mathrm{C}_{18: 0}$ & 4.32 & 3.9 & 1.7 & 4.0 & 2.3 \\
\hline Oleic $\mathrm{C}_{18: 1}$ & 19.42 & 22.8 & 25.8 & 16.5 & 17.3 \\
\hline Other & - & 4.5 & 0.6 & 0.5 & 0.6 \\
\hline Total saturation & 15.14 & 14.8 & 12.7 & 10.0 & 25.7 \\
\hline Total unsaturation & 84.86 & 80.7 & 86.7 & 89.5 & 73.7 \\
\hline Mono unsaturation & 21.54 & 23.1 & 25.8 & 16.6 & 17.9 \\
\hline
\end{tabular}

\subsection{Composition of unsaponifiable matter}

The composition of unsaponifiable matter of PPSO using GC/MS is listed in Table 4. It could be observed that two fractions were identified; stability of sunflower oil as affected by using different concentrations of USM, are displayed in 
Table (4): Composition of unsaponifiable matters of prickly pear seeds oil.

Component Relative percent

\begin{tabular}{ll}
\hline Sterolic fraction & \\
\hline$\beta$ - Sitosterol & 64.8 \\
Campesterol & 13.8 \\
Stigmasterol & 6.1 \\
Lanosterol & 5.8 \\
$\Delta$-5 Avenasterol & 4.4 \\
Total identified & 94.9 \\
Total un-identified & 5.1 \\
Alcoholic fraction & \\
24- Methyl cycloarthenol & 48.8 \\
Cycloarthenol & 35.9 \\
$\beta$-Amyrin & 6.4 \\
Total identified & 91.1 \\
Total un-identified & 8.9 \\
\hline
\end{tabular}

Table (5). It could be observed that USM at 400 ppm had a little effect on the induction period (3.8 days). A positive correlation between USM concentration and its antioxidative activities was noticed. At the concentration $1200 \mathrm{ppm}$, USM showed a similar induction period as BHT at 200 ppm where the induction period recorded 11.6 and 11.5 days, respectively.

Furthermore, USM exhibited higher antioxidant activity at $1500 \mathrm{ppm}$ compared to BHA as shown in Table 5. With reference to the antioxidant activity of USM, it could be ascribed

Table (5): Effect of unsaponifiable matters of PPSO at various concentrations on induction period of sunflower oil

\begin{tabular}{lcc}
\hline $\begin{array}{c}\text { Unsaponifiable matter } \\
\text { concentration (ppm) }\end{array}$ & $\begin{array}{c}\text { Induction } \\
\text { period (day) }\end{array}$ & R.I.P \\
\hline None & $* 3.2^{\mathrm{g}} \pm 0.10$ & 1.0 \\
200 & $3.8^{\mathrm{f}} \pm 0.27$ & 1.2 \\
400 & $3.8^{\mathrm{f}} \pm 0.35$ & 1.2 \\
600 & $5.8^{\mathrm{e}} \pm 0.20$ & 1.8 \\
800 & $7.5^{\mathrm{d}} \pm 0.27$ & 2.3 \\
1000 & $10.8^{\mathrm{c}} \pm 0.27$ & 3.4 \\
1200 & $11.6^{\mathrm{b}} \pm 0.35$ & 3.6 \\
1500 & $13.5^{\mathrm{a}} \pm 0.31$ & 4.2 \\
BHA $(200 \mathrm{ppm})$ & $11.5^{\mathrm{b}} \pm 0.3$ & 3.6 \\
\hline
\end{tabular}

* The initial peroxide value of the oil samples was 1.2 meq $\mathrm{O}_{2} / \mathrm{kg}$ oil.

${ }^{* * *}$ Induction period, days needed for peroxide value to become 20 at $75^{\circ} \mathrm{C} \pm 1$

\# R.I.P (Relative induction period):indction period for control= 1 .

Results are means of three determinations \pm standard deviations.

- Means which are not significantly different are followed by the same letter.

to the presence of sterol fraction as reported by (Ntanios, 2001 Ramadan and Morsel (2003) a and Salvo et al., (2004), where $\beta$ - sitosterol accounted to $64.8 \%$ of the total sterol content in PPSO (Table, 4).

Based on the abovementioned results, prickly pear seed oil singled out to be a good potential source of alimentary oil, besides, the activity of unsaponifiable matter against oxidation as a natural antioxidant, which could prolong the shelf life of edible fats and oils.

\section{REFERENCES}

AOAC (1995). Official Methods of Analysis, $16^{\text {th }}$ ed. AOAC International, Arlington, Virginia, USA.

AOCS (1993). Official Methods and Recommended Practices of the American Oil Chemists' Society, $4^{\text {th }}$ ed. Champaigne, Illnois, USA.

Banias C. ,Oreopoulou V. and Thomopoulos C.D. (1992). The effect of primary antioxidants and synergists on the activity of plant extracts in Lard. JAOCS, 69 (6): 520-524.

Barbagallo R.N. and Spagna G. (1999). Fatty acid determination from oil seeds of Opuntia ficusindica L. Industrie- Alimentari; 38 (383): 815817.

Bereau D., Benjelloun-Mlayah B.; Banoub J. and Bravo R. (2003). Fatty acids and unsaponifianle composition of five Amazonian palm kernel oils. JAOCS, 80(1): 49-53.

Coskuner Y. and Tekin A. (2003). Monitoring of seed composition of prickly pear. J. Sci. Food Agric., 83(8): 846-849.

Duru B. and Turker N. (2005). Changes in physical properties and chemical composition of cactus pear (Opuntia ficus- indica) during maturation. J. PACD; 22-33.

Economou K. D., Oreopoulou V. and Thompoulos C. D. (1991). Antioxidant of some plant extracts of family Labiatae. JAOCS, 68 (1): 109-112.

Ennouri M., Evelyne B., M. and Attia H. (2005a). Fatty acid composition and rheological behaviour of prickly pear seed oils. Food Chem., 93: 431- 437.

Ennouri M., Fetoui H. , Bourret, E. and Zeghal N. (2005b). Evaluation of some biological parameters of Opuntia ficus- indica.L. Influence of a seed oil supplemented diet on rats. Bioresour. Technol., 97(12): 1382- 1386.

Hui Y.H. (1996). Bailey's Industrial oil and fat products. Edible oil and fat products: Oils and oilseeds. $5^{\text {th }}$ Ed. vol. 2. A Wiley- Interscience Publication, John Wiley\& Sons, Inc. New York, Toronto.

Jassen M.M.T. and Vries J. (1997). Food Safety and Toxicity. Part 1A, ch. 5.P 68. CRC Press, Boca Raton, New York.

Krifa M., Villet A., Krifa F. and Alary J. (1993). Prickly pear seed oil. Study of its 
composition. Annales des Falsification de chemique et Toxicologique, 86 (819): 161174.

Kuti J.O. (2004). Antioxidant compounds from four Opuntia cactus pear fruit varieties. Food Chem., 85(4): 527-533.

Lopez P.O. and Burgos R.R. (1973). Canned prickly pear juice. Technologia de Alimentos, 8(5):237-240.

Ntanios F. (2001). Plant sterol-ester-enriched spreads as an example of a new functional food. Eur. J. Lipid Sci. Technol., 103: 102106.

Piga A. (2004). Cactus pear. A fruit of nutraceutical and functional importance. J. PACD, 9-22.

Ramadan M. F. and Morsel J. T. (2003a). Lipid profile of prickly pear pulp fractions. Food, Agric. and Environ., 1(2): 66-70.

Ramadan M. F. and Morsel J. T. (2003b). Oil cactus pear (Opuntia ficus- indica). Food Chem., 82: 339-345.
Salvo F., Galati E. M.; Curto S. L. and Tripodo M. M.(2004). Chemical characterization of Opuntia ficus- indica seed oil. http://www. actahort. org .

Sawaya W. N. and Khan, P. (1982). Chemical characterization of prickly pear seed oil. J. Food Sci., 47 (8): 2060-2061

Snedecor G.W. and Cochran W.G. (1980). Statistical Methods $7^{\text {th }}$ Ed. The Iowa State Univ. Press, Ames, Iowa, USA.

Strecker L. R., Maza A. and Winnie F. G. (1990). C.F. Hui, Y.H. (1996). Bailey's Industrial oil and fat products. $5^{\text {th }}$ Ed. vol. 2. ch. 3 p.130. A Wiley- Interscience Publication, John Wiley \& Sons, Inc. New York, Toronto.

Tan C. P. and Che Man Y. B. (2000). Differential scanning colorimetric.analysis of oils:Comparison of thermal properties and chemical composition. JAOCS, 77 (2): 143155. 
analysis of edible oils: Comparison of thermal properties and chemical composition 